\title{
БІЛЬШОВИЦЬКА ТЕРМІНОЛОГІЯ ІДЕОЛОГІЧНОГО ВПЛИВУ НА УКРАЇНСЬКИХ ОСВІТЯН У РОКИ РЕПРЕСІЙ (1927-1937 pp.)
}

Анотація: У статті досліджено ідеологічну термінологію, яку більшовики використовували проти освітян Украӥни у роки масових репресій. Основний перелік понять складено за матеріалами періодичої преси та опублікованими архівними документами. Висвітлено найбільш використані терміни у 1927-1933 та 1934-1937рр., зазначено їх персоніфіковане та політичне походження. Ідеологічні ярлики («український фашизм», «буржуазний нащіоналізм», «український шовінізм» та інші) не відповідали реальним подіям та явищам в Україні. Їх застосовували для маніпуляції суспільною свідомістю, а також для ідеологічної профілактики в інститутах і загальноосвітній школі. Кожен термін означав вибір жертви політичних репресій: персональної, національної, соціальної або професійної групи. Політичні ярлики «хвильовизм», «шумськизм», «волобуєвщина», «троцькісти» й інші виконували функцію ідеологічної профілактики освітніх установ. Використання спеціальної термінології державними органами та ї̈ поширення у пресі створювало образ внутрішнього ворога, підвищувало так звану «політичну пильність» у суспільстві. Партійні організації та підрозділи ДПу здійснювали «кадрові чистки» 6 інститутах, університетах $і$ школах, шукали серед педагогів та учених «буржуазних націоналістів», «петлюрівщів», «махновців» $і$ різних «шкідників». Поширенням агресивної термінології займалися центральні, обласні, районні й інститутські газети.

Ключові слова: більшовицька термінологія, ідеологічний вплив, ДПУ УСРР, репресії, українські політичні партії, педагогічна освіта

Історіографія масових політичних репресій в Україні вражає кількістю праць, продовжується серія видань «Реабілітовані історією» (понад 100 томів). Історики встановлюють загальну кількість і персональний склад жертв сталінського політичного терору, функціонування системи ГУЛАГу. Системно досліджено карально-репресивний механізм, названо катів, висвітлено трагічні долі людей. Все частіше і частіше учені замислюються над питанням: чому це стало можливим? Соціальні верстви суспільства підтримали жовтневий переворот, а стримати червоний терор не змогли. Поза увагою історичної та політологічної дисциплін лишаються специфічні елементи легітимізації державного терору проти власних громадян: маніпуляція громадською думкою через публічне застосування ідеологічної термінології, навішування політичних ярликів, свідомого та послідовного нагнітання страху у суспільстві, стимулювання викриття всіляких шпигунів і «ворогів народу». Десять років сталінської модернізації суспільних відносин

\footnotetext{
* Виговський Микола Юрійович - доктор історичних наук, професор кафедри цивілізаційної історії та археології Центрально-Східної Європи Національного педагогічного університету імені М.П. Драгоманова (Київ, Україна);

ORCID: https://orcid.org/0000-0002-2874-5528; e-mail: zholobb@gmail.com
} 
вирізнялися різною інтенсивністю репресій, але за принципом снігової лавини. Від індивідуального, групового до масового фізичного винищення людей у 1927-1933 рр., враховуючи жертв Голодомору, до вибіркового за соціально-професійним походженням і партійною приналежністю та сумнівною опозиційністю у 1936-1937 pp. Облудна термінологія сталінсько-більшовицького терору намічала його потенційних жертв.

В українській історіографії є монографії та дисертаційні роботи з історії функціонування періодичної преси та політичної цензури'. Однак, у них лише згадуються статті 3 відповідною термінологією, але не вивчається ідеологічна мотивація застосування дивної за лінгвістичним походженням фразеології. Для нашого дослідження преса - це лише масове джерело, носій необхідної наукової інформації. На основі публікацій ми формуємо відповідну типологію, простежуємо інтенсивність появи замовних статей, аналізуємо іх політичне призначення і так зване «соціальне замовлення», термін і практика якого з'явилися саме тоді. На специфіку ідеологічної термінології звертали увагу історики М. Кузьменко та В. Марочко, досліджуючи становище науково-педагогічної інтелігенції в Україні, функціонування політичної цензури та репресій проти освітян ${ }^{2}$.

Статті 3 більшовицькою ідеологічною термінологією постають у монографії М. Виговського (2005) ${ }^{3}$, але значна частина матеріалів періодики не була в ній використана. Історики, цитуючи подібні статті, піддають сумніву достовірність визначень «український шовінізм», «буржуазний націоналізм», а також так звані судові процеси 1930-х рр. ${ }^{4}$ Виходячи $з$ принципу історизму, маємо сприймати події та явища такими, які відбувалися і відбулися. Низка термінів, крім функціональної агітки агітпропу ЦК КП(б)У, могла стати та ставала вироком для багатьох діячів культи, науки, освіти.

Предметна систематизація тематичних публікацій у газетах і частково журналах тих років - формальна частина нашого дослідження. Ключове завдання полягає у виявленні та змістовному аналізі назв статей за соціальним, національним, професійним, персональним і відомчим походженням, їх адресним призначенням. Важливо порівняти термінологічні фантазії працівників ідеологічного сектору ЦК КП(б)У, різного калібру сількорів, робкорів, партійних функціонерів у 1927-1933 і 1934-1937 рр. Які поняття та ярлики виникли уперше, які затримались у повсякденному ідеологічному ужитку, чим відрізнялися один від одного, набули сталої прописки в арсеналі соціально-психологічного впливу на професійні групи суспільства. Вони виходили (швидше їх виводили) на багатолюдні мітинги проти «шпигунів», «зінов’євців», «троцькістів» і «ворогів народу». Взаємодія слова і діла давала ситуативний ефект, засвідчувала формат ідеологічного впливу на суспільну свідомість.

\footnotetext{
${ }^{1}$ Коляструк 0.А. Преса УСРР в контексті політики українізації (20-30-ті роки ХХ століття): Автореф. дис... канд. іст. наук: 07.00.01 - «Історія України». Київ: Інститут історії України НАН України, 2003. 20 с.; Стоян Т.А. Система політичної цензури в УРСР у 1920-1930 pp. Київ: Академія праці та соц. відносин Федер. проф. спілок України, 2010. 480 с.

${ }^{2}$ Кузьменко М.М. Науково-педагогічна інтелігенція в УСРР 20-30-х рр.: соціально-професійний статус та освітньо-культурний рівень. Донецьк: НОРД-ПРЕС, 2004. 455 с.; Марочко В.I. Репресовані педагоги України: жертви політичного терору (1929-1941). Київ: Науковий світ, 2003. 302 с.

${ }_{3}^{3}$ Виговський М.Ю. Номенклатура системи освіти в УСРР 1920-1930-х років: соціальне походження, персональний склад та функції. Київ: «Генеза», 2005. 298 с.

${ }^{4}$ Шаповал Ю.І. Україна 20-50-х років: сторінки ненаписаної історії. Київ: Наукова думка, 1993. 349 с.
} 
Утвердження однопартійної політичної системи влади зумовило послідовну та неухильну ідеологізацію суспільного життя в Україні. Вона 3 усією агресивною радикальністю постає у фабрикації так званих «національних ухилів» наприкінці 1920-х рр.: «хвильовизм», «шумськизм», «волобуєвщина» ${ }^{5}$ Мотиви їх створення напрочуд прагматичні: профілактика будь-яких опозиційних течій і можливих «самостійницьких» рухів у партійному будівництві, унеможливлення економічних теорій про особливий статус України у «народногосподарському комплексі СРСР».

Одночасно з цими ідеологічними фразеологізмами з'явилися войовничі поняття, які постають у щотижневих зведеннях ДПУ УСРР про політичні настрої серед інтелігенції. Їх поява припадає на 1927-1929 рр., вражаючи безапеляційністю та категоричністю змісту: «український фашизм», «петлюрівщина», «автокефальщина», «зміновіхівська група», «антирадянська агітація», «шовіністи», «українське антирадянське угруповання», «шовіністичний дух», «антирадянська фізіономія», «шовіністична група», «шовіністичне учительство», «український націоналістичний вплив», «український шовінізм», «антирадянська інтелігенція», «національний антагонізм», «українські шовіністичні діячі», «антирадянська активність», петлюрівське угруповання», «українська контрреволюція», «український контрреволюційний актив», «економічна контрреволюція». «шовіністичні настрої», «права професура», «антирадянська діяльність», «гетьманці» (дуже рідко вживане тоді), «київські шовіністичні кола» (проти академіка і колишнього соціаліста-федераліста С. Єфремова та його оточення), «куркульсько-шовіністичне угруповання» ${ }^{6}$.

Окремі фразеологічні вирази ідеологічно та персонально стосувалися конкретних груп інтелігенції, колишніх українських політичних і церковних діячів: «петлюрівщина», «петлюрівське угруповання», «шовіністичне учительство», «київські шовіністичні кола». Авторами зазначених термінів та упорядниками оперативних зведень були працівники секретного відділу ДПУ УСРР на чолі з його начальником К. Карлсоном. Вони не дуже переймалися соціологічно-політичним змістом термінології, який не відповідав історичним реаліям суспільного життя в Україні кінця 1920-х рр. Наприклад, оригінальне формулювання «куркульсько-шовіністичне угруповання» стосувалося заможних селян 3 явними антирадянськими настроями, які виступали проти політики хлібозаготівлі". Базовим підгрунтям для конструювання термінів 3 ключовим словом «шовінізм» були антисемітські настрої населення міст і сіл у побуті, а не програмні засади діячів «колишніх» українських партій. Шовіністичним вважалося протистояння русифікації, просування української мови у вищих навчальних закладах і школі, а соціальним індикатором впливу «українського шовінізму» невдоволення «правої професури» активною українізацією системи освіти. Агенти ДПУ, яких чимало було у різних колах української інтелігенції та серед «колишніх» одно партійців доби УНР, доповідали про ознаки принципового протистояння «українського автономізму з великоросійським шовінізмом», а «махровим

\footnotetext{
${ }^{5}$ Новохатько Л.М. Волобуєв М. і «волобуєвщина» (загадкова історія походження українського «сепаратизму»). Київ, 1997. 129 с.; Пристайко В. Справа «Спілки Визволення України»: невідомі документи і факти. Київ: Інтел, 1998. 446 c.

${ }^{6}$ Даниленко В.М. Українська інтелігенція і влада: Зведення секретного відділу ДПу уСРР 1927-1929 рр. Київ: Темпора, 2012. С. 71, 78, 108, 293, 317, 483.

${ }^{7}$ Ibid. C. 495.
} 
великоруським шовіністом на Україні» вважали Л. Кагановича. На ці обставини зверталася увага у зведеннях ДПУ за 6-12 травня 1928 р. ${ }^{8}$

Більшовицька термінологія, яка мала усі ознаки соціально-класового шовінізму, не була формальною та пасивною дефініцією. За кожним терміном відбувалися каральнорепресивні дії слідчих органів ДПУ УСРР. Ідеологічний ярлик, повішений на ту чи іншу особу, означав політично умотивований вибір жертви. У 1927 р. органи ДПУ арештували 1371 особу, серед яких 107 від «української громадськості», 226 священиків («реалізація терміну «автокефалыщина»), 22 «колишніх комуністів», 17 меншовиків, 44 колишніх есерів і українських соціал-демократів, 9 «укапістів» (члени Української комуністичної партії) та 13 3 «куркульського угруповання» ${ }^{9}$. Майже чверть піддали адміністративному виселенню. Ярлик політично «неблагонадійного», особливо 3 позначкою «антирадянська агітація», змушував багатьох осіб на співпрацю з органами ДПУ в якості таємних агентів. Ними були завербовані у 1927 р. 95 з «української громадськості», 48 колишніх меншовиків, 39 есерів, 5 соціал-демократів, навіть по одному «махновцю» та укапісту. Наступного року кількість арештованих досягла 1833 осіб, а представники «української громадськості» становили 285, від духівництва 253, від «опозиціонерів» (термін тих років) 246, а також 49 «антирадянської молоді», 56 есерів, 24 «антисеміта», 21 «махновця». 4 соціал-демократа, 7 «хліборобівдемократів», 33 «колишніх комуністів», 23 анархіста, виславши 379 осіб. Сумна політична статистика, яка зайвий раз доводить прикладне застосування репресивної термінології, а не бутафорської фразеології кабінетних чиновників. Працівники секретного відділу ДПу займалися конкретною класифікацією «антирадянських елементів» за ідеологічними лекалами партійних органів.

3 метою «пришвидшення» роботи відбувалося активне вербування агентів. у 1928 р. ДПУ вдалося «розробити» 303 осіб з «української контрреволюції», 50 лівих есерів і 31 колишнього члена українських есерів, 16 соціал-демократів, навіть 14 «махновців», одного соціаліста-федераліста, трьох кадетів і 8 укапістів, а разом 1405 осіб ${ }^{10}$. Тандем підступної теорії та злочинної практики поглинав людей: одних засуджували до таборів, інших ламали морально і психологічно.

Упродовж другої половини 1929 р., маніпулюючи ідеологічною фразеологією та громадською думкою, співробітники ДПУ активно готували судовий процес у справі «Спілки Визволення України» (СВУ). Вони арештовували, допитували та вербували не лише «київські шовіністичні кола», а також представників «української контрреволюції» на місцях (вигадані осередки «СВУ») $)^{11}$. Проведення судового процесу - закономірний підсумок ідеологічно-інформаційного впливу на суспільну свідомість, на професійні кола освітян, формуючи ознаки «української контрреволюції. Навіть публікація казок Г.Х. Андерсона вважалася «проривом ідеологічного фронту» ${ }^{12}$.

\footnotetext{
${ }^{8}$ Ibid. C. 356.

${ }^{9}$ Ibid. C. $240-241$.

${ }^{10}$ Ibid. C. $474-475$.

${ }^{11}$ Українська контрреволюція перед пролетарським судом. Справа «Спілки Визволення України». Комуніст. 1930. 23 березня.

${ }^{12}$ Прорыв идеологического фронта. Пролетарий (Харьков). 1929. 22 августа.
} 
Справа «СВУ» набула широкого розголосу у пресі. Ї̈̈ організатори розраховували на широке обговорення у «трудових колективах», на кафедрах IHO, у школах, щоб створити прецедент викриття. Газета «Народній учитель» спочатку писала про права учителів на землекористування, про соціальні причини самогубств педагогів, про умови нарахування учителям пенсій, а з листопада 1929 р. несподівано заявила про «замах рештків української контрреволюціï, про «хитання на ідеологічному фронті», про «політичне шкідництво у школі». Словник ідеологічних фраз поповнювався новими формулюваннями, серед яких проскакував дзвіночки - «наш ворог», «шкідництво». Фактично і процедурно у 19271929 рр. були адаптовані та застосовані агресивні за суттю ідеологічні ярлики. Процес «СВУ» надав особливого звучання цим неологізмам репресивної машини, тому газети рясніли заголовками «Українська контрреволюція перед пролетарським судом», друкуючи хроніку засідань суду ${ }^{13}$. Зловісний тандем облудної термінології та злочинної практики заявив про свої наміри та дії.

Форсування темпів масової колективізації та індустріалізації, посилення хлібозаготівельної політики, насаджування соціального замовлення та методу соцреалізму у мистецтві, літературі, перегляд навчальних планів і шкільних програм, реформування системи освіти - неоднозначно сприймалися у суспільстві. Білышовицька пропагандистська машина, використовуючи терор і профілактичні кампанії, діяла на упередження. Агресивна риторика та показові судові процеси впливали на соціально-політичні настрої інтелігенції, освітян. У суспільстві поступово виникало відчуття реально існуючих шпигунів, «ворогів народу». Більшовицькі газети, а інших не було в УСРР, перетворилися на рупор системного та щоденного ідеологічного тиску, шельмування і викриття «антирадянських елементів». У 1929-1934 рр., за неповними підрахунками автора, газети опублікували 115 замовних статей викривального характеру, спрямованих проти освітян. А протягом 1935-1937 рр. цієї «інтелектуальної» продукції, особливо у 1934 і 1937 р., вийшло понад 200 назв. Редактори, редколегії, штатні політичні цензори чекали від ЦК КП(б)У політичних настанов щодо «викриття шкідництва», Наприклад, справа «Українського Національного Центру» розглядалася на засіданні політбюро ЦК КП(б)У 22 березня 1931 р., тому що серед iї фігурантів було близько 30 «колишніх» українських есерів, соціалдемократів (М. Грушевський, М. Шраг, В. Мазуренко, І. Лизанівський, Н. Петренко, М. Чечель, П. Височанський, В. Голубович та інші). Вони уособлювали політичну еліту української революції, а на процесі стали «українською контрреволюцією». Процес був закритим, тому преса не дуже широко висвітлювали обставини, але колишній український есер П.Любченко встиг відреагувати на «контрреволюційні змови і запроданство» ${ }^{14}$. Сфабрикована справа «УНЦ» була перманентним продовженням судилища «СВУ», але 3 іншими персоналіями та новими ідеологічними ярликами. У профільних журналах навіть виділили рубрику про «шкідництво на педагогічному фронті». Віртуози демонічної фразеології змагалися у мовній вишуканості: «соціал-фашисти українського гатунку на фронті шкідництва» ${ }^{15}$. Дивовижне словоблуддя, яке не відповідало реальності, але вражало фантазією.

\footnotetext{
${ }^{13}$ Українська контрреволюція перед пролетарським судом. Справа «Спілки Визволення України». Комуніст. 1930. 23 березня.

${ }^{14}$ Любченко П. Документ про контрреволюційні змови і запроданство. Вісті ВУЦВК. 1931. 2 серпня.

${ }^{15}$ Тараненко П. Шкільна практика українського фашизму. Комуністична освіта. 1931. № 4-5. С. 92-105.
} 
У роки Голодомору, коли суспільство опинилося на межі вимирання, інформаційна війна не вщухала. Винирнули 3 глибини партійних кабінетів політичні кліше персонального призначення: «троцькістська контрабанда» і «гнилий лібералізм» окремих керівників в Україні ${ }^{16}$. Але яке відношення до неї мали звичайні педагоги загальноосвітньої школи. Оригінальністю вирізнялося визначення «меншовицько-есерівська контрабанда» ${ }^{17}$, хоч ці партії не були політичними союзниками. Ідеологічні підрозділи ЦК КП(б)У налаштовували штатних і позаштатних агітпропівців на поширення у пресі публікацій 3 войовничою термінологією. Вона впливала на багатотисячну аудиторію освітян, а також на студентів, формуючи у них ідеологічні норми соціальної поведінки.

Особливістю конструювання та поширення у пресі агресивної термінології стало залучення до її творення номенклатурних посадовців. У 1933-1934 рр. у газетах і журналах друкувалися промови та статті В.Затонського, А. Хвилі, І.Хаїта, тобто справді «меншовицько-есерівський союз». До прикладу І. Хаїт (заступник наркома освіти) розмірковував над поєднанням педагогіки і політики, спільної діяльності Українського науково-дослідного інституту педагогіки та Всеукраїнського товариства «Педагогмарксист» ${ }^{18}$. Термінологічні хвилі, особливо від їх збурення одіозним заступником наркома освіти А. Хвилею (колишній есер), набули ознак тривалої ідеологічної кампанії. Старого терміну «український фашизм» виявилося замало, тому запропонували особливу фразеологічну суміш: «буржуазно-націоналістичні правоопортуністичні теорії» ${ }^{19}$. У статтях, які стосувалися теорії і практики радянської педагогіки, стали обов'язковими терміни «націоналіст-петлюрівець», «буржуазні теорії, «буржуазно-націоналістичні елементи», «буржуазні націоналісти». У публікаціях лунали відверті заклики «розгромити до кінця буржуазний націоналізм» і «зламати ворога». Україна, як аграрна країна, не спромоглася сформувати своєї національної буржуазії, а тим паче створити подібні партії 3 програмними засадами «буржуазного націоналізму». Войовнича термінологія про його загрозу лунала у промовах наркома освіти В. Затонського на похоронах історика і політика М. Грушевського 14 грудня 1934 p. ${ }^{20}$ у статті письменника А. Сенченка і Т. Постоловської (дружина П. Постишева) також був заклик «розгромити до кінця рештки контрреволюційних націоналістів і троцькістів» ${ }^{21}$. Інколи особи такого рівня намагалися застерегти себе від ідеологічних і політичних звинувачень у пасивному ставленні до «буржуазних націоналістів». Поєднання українських буржуазних націоналістів 3 троцькістами виявилося занадто революційним.

У 1935-1936 рр., коли в Україні репресивні органи добивали колишніх боротьбистів, виявляли «зінов'євців», «троцькістів», газети не зупинялися у закликах «розгромити буржуазних націоналістів». Майже зник зі шпальт колись поширений термін «націонал-

\footnotetext{
${ }^{16}$ Мітрофанов. «Записки ІСВ»: рупор троцькістської пропаганди. Листи до редакції «Більшовик». Більшовик Полтавщини. 1932.17 січня.

${ }^{17}$ Койнаш П. Проти меншовицько-есерівської контрабанди. Більщовик Полтавщини. 1932. 29 січня.

${ }^{18}$ Xaїm I. Педагогіка і політика (Про УНДІП та Всеукраїнське товариство «Педагог-марксист». Комуніст. 1933.

21 жовтня.

${ }^{19}$ За більшовицького педагога (Харків). 1933 (третя декада листопада).

${ }^{20}$ Промова тов. Затонського на похоронах Грушевського. Комуніст. 1934. 14 грудня.

${ }^{21}$ Сенченко А., Постоловська Т. Розгромити до кінця рештки контрреволюційних націоналістів і троцькістів. Комуніст. 1934. 7 листопада.
} 
ухильники» $»^{22}$ Конкурентну здатність виявили два найпоширеніші поняття «буржуазний націоналізм» і «троцькістські недобитки». Виник дивний за соціальним походженням фразеологізм «буржуазні переродженці», адже Неп було ліквідовано наприкінці 1920-х рр. Лінгвістично смачно виглядав вираз «куркульсько-петлюрівський націоналізм» ${ }^{23}$. Неочікуваним, враховуючи діяльність колишнього міністра освіти ЗУНР А. Крушельницького, було зарахування його до групи «терористів-білогвардійців», яких військова колегія Верховного суду СРСР у м. Києві засудила до розстрілу у грудні 1934 p. ${ }^{24}$

У сумнозвісному 1937 р. інтенсивність публікацій з репресивними гаслами набула ознак кампанії, але термінологічні фантазії працівників агітпропу ЦК КП(б)У та структур НКВС УСРР вичерпались. Стабільним та універсальним лишався термін «буржуазний націоналізм», інколи використовували нове тлумачення «націоналістичне охвістя», тобто «рештки», а не залишки. Активніше почали закликати дій 3 наміром - «розгромити», «викорчувати», «викоренити» ворогів різних кольорів і відтінків. Заклики стосувалися звичайних сільських і міських педагогів ${ }^{25}$. Теоретичні поняття трансформувалися у відверті образливі ярлики: «націоналістична погань», «ворожа наволоч», «націоналістичне кубло», «вороже кубло», «замаскований ворог», «дворушник» (кілька випадків). Соціальна група репресованих розширилася, тому вигадали новий термін - «покровителі буржуазних націоналістів» ${ }^{26}$, тобто не їх ідейні наставники, а звичайні трудові колективи, в яких виявили «націоналіста».

Ідеологи застосування поняття «буржуазний націоналізм» орієнтувалися не на внутрішній соціальний контингент, а на активну діяльність української політичної еміграції. Очевидно, з огляду на її активність та організаційні форми (УНДО, ОУН тощо), більшовицьке керівництво припускало можливість якогось реального чи ментального союзу 3 інтелігенцією в УСРР. Внутрішні «буржуазно-націоналістичні елементи» не загрожували радянській владі. Опозиційну загрозу могли скласти «націонал-ухильники» 3 колишніх українських політичних партій наприкінці 1920-х рр., ніж вигадані у кремлівських ідеологічних кабінетах «українські буржуазні націоналісти».

Отже, підсумовуючи текстологічний аналіз публікацій періодичної преси, документальні джерела, можна упевнено говорити про системне використання ідеологічної термінології для впливу на суспільну свідомість. Більшовицька войовнича термінологія правила за інструмент державного управління, маніпулювання громадською думкою, спрямування іï у бажане русло. Концентрація уваги на «українському буржуазному націоналізмові» засвідчувала не лише упереджене ставлення до українського політичного руху доби УНР, але й насторожене ставлення більшовиків до будь-яких проявів українського самостійного руху (персонального «ухилу», поширення чуток про минуле, «економічного сепаратизму», коливань генеральної лінії партії). Комуністичний режим опирався на силові структури та масові репресії, але остерігався реального

\footnotetext{
${ }^{22}$ Горб А. За очищення історичного фронту від решток націонал-ухильників. Зоря. 1934. 26 червня.

${ }^{23}$ Шабловський $\Theta$., Колесник П. Проти куркульсько-петлюрівського націоналізму в художній літературі. Пролетарська правда. 1933. 24 березня.

${ }^{24}$ Присуд військової колегії Найвищого суду Союзу РСР у м. Києві в справах про терористів-білогвардійців. Ленінська зміна. 1934.18 грудня.

${ }^{25}$ М.Н. Викорчувати націоналістичне охвістя в Ізюмській педшколі. Ленінська зміна. 1937. 10 жовтня.

${ }^{26}$ Барановський Ю. Покровителі буржуазних націоналістів. Більшовик (Чернігів). 1937. 17 вересня.
} 
ухильництва у свідомості, тому ідеологічна термінологія мала унеможливити будь-які форми його зародження у головах учених, у навчальних програмах і підручниках системи освіти, на кафедрах інститутів та університетів, на заводах і фабриках. Профілактичним засобом їх появи були облудні ідеологічні страшилки і цілком реальні політичні процеси.

\section{Mykola Vyhovskyi}

\section{Bolshevik Terminology of Ideological Influence on Ukrainian Educators during the Years of Repressions (1927-1937)}

The article explores the ideological terminology used by the Bolsheviks against Ukrainian educators during the years of mass repressions. The main list of concepts is compiled of the materials from the periodicals and the published archive documents. There are highlighted the most used terms of 1927-1933 and 1934-1937, their personalized and political origin is indicated. Ideological labels («Ukrainian fascism», «bourgeois nationalism», «Ukrainian chauvinism» and others) did not correspond to real events and phenomena in Ukraine. They were used to manipulate public consciousness, as well as for ideological prevention in institutes and schools. Each term meant the choice of a victim of political repression: personal, national, social or professional group. Political labels «Khvylovism», «Shumskism», «Volobuevshchina», «Trotskists» and others performed the function of ideological prevention of educational institutions. The use of special terminology by state authorities and its distribution in the press was creating the image of an internal enemy, was increasing the socalled «political vigilance» in society. Party organizations and subdivisions of the DPU carried out «personnel cleansing» in institutes, universities, and schools, and sought among teachers and scientists the «bourgeois nationalists», «Petliurists», «Makhnovists», and various «pests». Central, regional, district and institute newspapers were involved in spreading of aggressive terminology.

Keywords: Bolshevik terminology, ideological influence, DPU UkrSSR (State Political Administration of Ukrainian Soviet Socialist Republic), repressions, Ukrainian political parties, pedagogical education 